$\xi=-1$

\title{
Lowering blood sugar levels with kersen leaf stew (muntingia calabura l) and black onion (alium sativum) extract in mice (mus musculus)
}

\author{
Eni Sumarliyah ${ }^{1}$ Dede Nasrullah ${ }^{1} *$, Sukadiono ${ }^{2}$, Desta Pankyano ${ }^{1}$ \\ ${ }^{1}$ Department Nursing Faculty Health of Science University Muhammadiyah of Surabaya, Indonesia \\ ${ }^{2}$ Faculty of Medicine University of Muhammadiyah Surabaya, Indonesia \\ *Corresponding author E-mail: dedenasrullah@um-surabaya.ac.id
}

\begin{abstract}
Diabetes mellitus (DM) is a metabolic disease characterized by an increase in blood sugar levels. Blood sugar levels in patients with DM are mostly challenging to control, and this will threaten the occurrence of complications. Alternative therapies used are active flavonoids in reducing blood glucose. The purpose of this study was to analyze the decrease in blood sugar levels by administering cherry leaves stew and black onions to mice (mus musculus). The design of this study was the Quasy Experimental design (pretest-posttest with control group design). The sample in this study was 32 mice, 16 in the intervention group, and 16 comparison groups. There are independent variables (Kersen Leaf Stew and Black Onion Extract) and the dependent variable (Blood Glucose Level). The data were collected using an observation sheet, then analyzed using the independent sample T-test and Kolmogorov Smirnov test. The results of this study showed that the pre and post administration of cherry leaf decoction was $36.5 \mathrm{mg} / \mathrm{dl}$, and the difference between pre and post administration of black onion extract was $24.3 \mathrm{mg} / \mathrm{dl}$. While the analysis showed $\mathrm{p}=$ value 0.98 , it showed no difference in the effectiveness of the two extracts in reducing blood sugar levels in mice. Obtained comparative test results from the two extracts were equally effective in lowering blood sugar in mice. Thus further research needs to be done with more samples.
\end{abstract}

Keywords: Diabetes Mellitus; Kersen Leaf; Black Onion Extract; Blood Glucose Level; Mice (Mus Musculus).

\section{Introduction}

Diabetes mellitus (DM) is a disease in which the condition of glucose levels in the blood exceeds normal limits. WHO estimates that the prevalence will increase every year? One problem that arises in patients with diabetes mellitus is their difficulty in controlling blood sugar levels, which will have the potential for them to be uncontrolled blood sugar levels. According to Masfufah (2013), most patients with Diabetes Mellitus have unstable or high blood sugar levels[1].

Based on the results of research conducted by Masfufah (2013), 36 patients were regularly check fasting blood sugar levels and as many as $16.7 \%$ of patients have good blood sugar levels of less than $100 \mathrm{mg} / \mathrm{dl}$, while $5.5 \%$ of patients have blood sugar levels between 100 $126 \mathrm{mg} / \mathrm{dl}, 77.8 \%$ have bad or uncontrolled blood sugar levels because of more than $126 \mathrm{mg} / \mathrm{dl}$ in the health center in Makassar[1]. The prevalence of diabetes mellitus, according to IDF (2015) states that the prevalence of diabetes is increasing every year. In 2015 diabetes reached 415 million people, and in 2017 it reached 425 million people. According to Riskesdas, from 2013 to 2018 , the prevalence of diabetes increased by $6.9 \%$ to $8.5 \%$, meaning that there was less than 22.9 million population prevalence of diabetes[2]. It is because Indonesia is in transition, demography, Technology, epidemiology, culture, behavior, and others.

Blood sugar levels increase because of several factors, including carbohydrates, physical activity, drug use, illness, stress, menstrual cycles, dehydration, and alcohol consumption. These conditions decreased glucose uptake due to the sensitivity of insulin receptors and decreased insulin action. Thus, if it left to cause hyperglycemia, which can cause complications in the body's organs, i.e. acute and chronic complications, one of the ways to prevent these complications is by the management of normalizing insulin activity and lowering blood sugar levels. Components in the management of diabetes mellitus are education, medical nutrition therapy, physical exercise, pharmacological medicine, and non-medical [3].

Diabetes management can be pharmacologically and non-pharmacologically. Among non-pharmacological therapies is the administration of herbal medicines, one of which is with cherry leaves and black onions[4]. As an antidiabetic Mellitus, Kersen Leaves (Multingia calabura) limited used and less popular than others, such as Brotowali or Sambiluto. The efficacy of this Tiliacea family member plant is to reduce blood glucose (Ahmad Ridwan and Rakhmi Ramadani in 2008) by testing the antidiabetic efficacy of Kersen leaves in 28 mice with diabetes due to alloxan injections. The test carried out for 15 days; each time, the measurement group continues to experience a decrease in blood glucose [5]. However, this study used Kersen Leaf extract, where a polar and non-polar ingredient would enter the extract and dissolve. While people in Papua have been using water as a solvent to draw polar compounds, so this study wants to prove that Kersen Leaves stew still affects reducing blood glucose levels. 
Heated black onions are fresh garlic (Allium sativum L.) for some time at controlled high temperatures $\left(60-90{ }^{\circ} \mathrm{C}\right)$ with controlled high humidity (80-90\%). When compared with fresh garlic, black onions do not produce a robust offensive taste due to reduced levels of allicin. Its bioactivity compared to fresh garlic is associated with changes in physicochemical properties. Black onions have more precious nutrients and increased biological activity and broader application prospects [6]. The total phenolic content in black garlic is 5-8 times higher than fresh garlic, so black garlic has higher antioxidant activity than fresh garlic [7]. Many valuable components in black onions, notably polyphenols, flavonoids, and some Maillard reaction substances known as anti-oxidant agents. Flavonoid thought to restore insulin receptor sensitivity to cells, thus decreases blood glucose levels, besides flavonoid as an antioxidant that can repair $\beta$ cells that have been damaged by free radicals [8].

\section{Methodology}

The design of this study was Quasi-Experimental with treatment before and after using Kersen leaf stew as well as a treatment before and after reducing blood sugar levels of mice with black onions. This type of research was the One Group Pre Test approach post-test; treated both experimental groups while the study did not use a control group. In both groups, the pre-test started, and after completing the treatment, measurements were retaken (post-test) [9]. The samples used were 32 mice divided into 16 mice by giving cherry leaves and the others by black onion extract. The data were collected using an observation sheet, then analyzed by using Kolmogorov Smirnov and independent sample T-test.

\section{Result}

\subsection{Identification of decreased blood sugar levels by providing kersen leaves}

Tabel 1: Blood Glucose Levels before and after Intervention Is Given to the Group of Gersen Leaf Decoction

\begin{tabular}{|c|c|c|c|}
\hline \multirow{2}{*}{ Sample Number } & \multicolumn{2}{|c|}{ Glucose levels of Kersen Leaf Extract (mg/dl) } & \multirow[t]{2}{*}{ Deviation $\mathrm{mg} / \mathrm{dl}$} \\
\hline & Pre & Post & \\
\hline 1 & $581 \mathrm{mg} / \mathrm{dl}$ & $155 \mathrm{mg} / \mathrm{dl}$ & -426 \\
\hline 2 & $250 \mathrm{mg} / \mathrm{dl}$ & $154 \mathrm{mg} / \mathrm{dl}$ & -96 \\
\hline 3 & $313 \mathrm{mg} / \mathrm{dl}$ & $88 \mathrm{mg} / \mathrm{dl}$ & -225 \\
\hline 4 & $246 \mathrm{mg} / \mathrm{dl}$ & $167 \mathrm{mg} / \mathrm{dl}$ & -79 \\
\hline 5 & $276 \mathrm{mg} / \mathrm{dl}$ & $128 \mathrm{mg} / \mathrm{dl}$ & -148 \\
\hline 6 & $290 \mathrm{mg} / \mathrm{dl}$ & $107 \mathrm{mg} / \mathrm{dl}$ & -183 \\
\hline 7 & $330 \mathrm{mg} / \mathrm{dl}$ & $188 \mathrm{mg} / \mathrm{dl}$ & -142 \\
\hline 8 & $526 \mathrm{mg} / \mathrm{dl}$ & $151 \mathrm{mg} / \mathrm{dl}$ & -375 \\
\hline 9 & $534 \mathrm{mg} / \mathrm{dl}$ & $204 \mathrm{mg} / \mathrm{dl}$ & -330 \\
\hline 10 & $367 \mathrm{mg} / \mathrm{dl}$ & $81 \mathrm{mg} / \mathrm{dl}$ & -286 \\
\hline 11 & $294 \mathrm{mg} / \mathrm{dl}$ & $181 \mathrm{mg} / \mathrm{dl}$ & -113 \\
\hline 12 & $581 \mathrm{mg} / \mathrm{dl}$ & $181 \mathrm{mg} / \mathrm{dl}$ & -400 \\
\hline 13 & $405 \mathrm{mg} / \mathrm{dl}$ & $159 \mathrm{mg} / \mathrm{dl}$ & -246 \\
\hline 14 & $313 \mathrm{mg} / \mathrm{dl}$ & $63 \mathrm{mg} / \mathrm{dl}$ & -250 \\
\hline 15 & $234 \mathrm{mg} / \mathrm{dl}$ & $103 \mathrm{mg} / \mathrm{dl}$ & -131 \\
\hline Mean & 369,375 & 142,5 & $-226,87$ \\
\hline Std.dev & 120,7984 & 42,35564 & 110,7025 \\
\hline
\end{tabular}

The results of the 16 mice examined showed that the total blood sugar results before administration of kerosene leaf stew were 5,910 $\mathrm{mg} / \mathrm{dl}$ with an average of $396.4 \mathrm{mg} / \mathrm{dl}$. Whereas after treatment, the total amount of blood sugar was 2,280 $\mathrm{mg} / \mathrm{dl}$. The average blood sugar level was $142.5 \mathrm{mg} / \mathrm{dl}$. Thus, the decrease that occurred was $3,630 \mathrm{mg} / \mathrm{dl}$. The average decreased in blood sugar levels was 226.87 $\mathrm{mg} / \mathrm{dl}$ while the standard deviation before the action was 120.80 after the action was 42.36 and the reduction in blood sugar levels was 110.7 .

\subsection{Identification of decreased blood sugar levels by providing black onion extract}

Tabel 2: Identification of Blood Glucose Levels before and after Intervention in the Treatment Group Giving Black Onion Extract

\begin{tabular}{|c|c|c|c|}
\hline \multirow{2}{*}{ Sample Number } & \multicolumn{2}{|c|}{ Glucose levels of Black Onion Extract (mg/dl) } & \multirow[t]{2}{*}{ Deviation $\mathrm{mg} / \mathrm{dl}$} \\
\hline & Pre & Post & \\
\hline 1 & $235 \mathrm{mg} / \mathrm{dl}$ & $160 \mathrm{mg} / \mathrm{dl}$ & -75 \\
\hline 2 & $294 \mathrm{mg} / \mathrm{dl}$ & $103 \mathrm{mg} / \mathrm{dl}$ & -191 \\
\hline 3 & $370 \mathrm{mg} / \mathrm{dl}$ & $193 \mathrm{mg} / \mathrm{dl}$ & -177 \\
\hline 4 & $226 \mathrm{mg} / \mathrm{dl}$ & $158 \mathrm{mg} / \mathrm{dl}$ & -68 \\
\hline 5 & $430 \mathrm{mg} / \mathrm{dl}$ & $115 \mathrm{mg} / \mathrm{dl}$ & -315 \\
\hline 6 & $313 \mathrm{mg} / \mathrm{dl}$ & $155 \mathrm{mg} / \mathrm{dl}$ & -158 \\
\hline 7 & $234 \mathrm{mg} / \mathrm{dl}$ & $114 \mathrm{mg} / \mathrm{dl}$ & -120 \\
\hline 8 & $507 \mathrm{mg} / \mathrm{dl}$ & $194 \mathrm{mg} / \mathrm{dl}$ & -313 \\
\hline 9 & $290 \mathrm{mg} / \mathrm{dl}$ & $172 \mathrm{mg} / \mathrm{dl}$ & -118 \\
\hline 10 & $228 \mathrm{mg} / \mathrm{dl}$ & $145 \mathrm{mg} / \mathrm{dl}$ & -83 \\
\hline 11 & $234 \mathrm{mg} / \mathrm{dl}$ & $99 \mathrm{mg} / \mathrm{dl}$ & -111 \\
\hline 12 & $241 \mathrm{mg} / \mathrm{dl}$ & $123 \mathrm{mg} / \mathrm{dl}$ & -118 \\
\hline 13 & $305 \mathrm{mg} / \mathrm{dl}$ & $203 \mathrm{mg} / \mathrm{dl}$ & -100 \\
\hline 14 & $270 \mathrm{mg} / \mathrm{dl}$ & $159 \mathrm{mg} / \mathrm{dl}$ & -111 \\
\hline 15 & $448 \mathrm{mg} / \mathrm{dl}$ & $220 \mathrm{mg} / \mathrm{dl}$ & -228 \\
\hline 16 & $303 \mathrm{mg} / \mathrm{dl}$ & $203 \mathrm{mg} / \mathrm{dl}$ & -100 \\
\hline Total & 4928 & 2492 & -2436 \\
\hline Mean & 308 & 155.75 & $-152,25$ \\
\hline
\end{tabular}


The results of the 16 mice examined showed that total blood sugar results before administration of black onion extract were 4,928 mg/dl with an average of $308 \mathrm{mg} / \mathrm{dl}$. Whereas after treatment, the total amount of blood sugar was $2.492 \mathrm{mg} / \mathrm{dl}$. The average blood sugar level was $155.75 \mathrm{mg} / \mathrm{dl}$. Thus the decrease that occurred was 2,436 mg/dl. The average decrease in blood sugar levels was $152.25 \mathrm{mg} / \mathrm{dl}$, while the standard deviation before the action was 87.12 after the treatment was 37.10 , and the reduction in blood sugar levels was 76.10 .

\subsection{Differential analysis of blood sugar decreased by providing black onion and kersen leaves}

Tabel 3: Analyzing the Difference in Blood Sugar Levels before and after Treatment in Both Groups of Kersen Leaves and Black Onion Extract

\begin{tabular}{|c|c|c|}
\hline Sample Number & $\begin{array}{l}\text { Kersen Leaf Stew } \\
\text { Deviation }\end{array}$ & $\begin{array}{l}\text { Black Onion Extract } \\
\text { Deviation }\end{array}$ \\
\hline 1 & 426 & 75 \\
\hline 2 & 96 & 191 \\
\hline 3 & 225 & 177 \\
\hline 4 & 79 & 68 \\
\hline 5 & 148 & 315 \\
\hline 6 & 183 & 158 \\
\hline 7 & 142 & 120 \\
\hline 9 & 330 & 118 \\
\hline 10 & 286 & 83 \\
\hline 11 & 113 & 135 \\
\hline 12 & 421 & 118 \\
\hline 13 & 246 & 126 \\
\hline 14 & 250 & 111 \\
\hline 15 & 131 & 228 \\
\hline 16 & 200 & 100 \\
\hline $\mathrm{p}$ value & 0,985 & \\
\hline
\end{tabular}

The data distributed normally and tested using the Kolmogorov-Smirnov normality test. Then the data was carried out with the Independent Sample T-test using SPSS 16.0. The statistical test results by the Independent Sample T-test in both groups showed that $\mathrm{p}=0.98$, with a significance level of 0.05 , then $\mathrm{p}=0.98>\alpha 0.05$. Thus, H0 was accepted, and H1 was rejected, meaning that there was no significant difference in glucose levels blood in both groups of Kersen leaf stew and black onion extract. Both treatments were equally effective in reducing blood sugar levels.

\section{Discussion}

\subsection{Identification of decreased blood sugar levels by providing kersen leaves}

The results showed that the average blood glucose level in the treatment group before administering the Kersen leaves stew Stew averaged $396.4 \mathrm{mg} / \mathrm{dl}$. After administering, it decreased to $142.5 \mathrm{mg} / \mathrm{dl}$.

Decreased in blood sugar levels was the following research conducted by Zahroh (2016), that Kersen leaves could reduce blood glucose levels. One of the quite high substances in Kersen leaf stew is saponin and flavonoid, which can secrete insulin needed by the body for glucose metabolism [5]. Researchers reported that Kersen leaves could reduce blood glucose levels in mice with diabetes that related to the biological activity of its compounds.

The Kersen leaf stew empirically has been widely used by the public. However, it has not been proven scientifically effective, so this research aimed to determine its effectiveness in reducing blood glucose levels in the studies using a $40 \%$ dextrose administration aimed to raise blood glucose levels. Tested animals used were male mice because they have a more stable hormonal system compared to female mice that have glucose levels strongly influenced by hormones so that they could affect the results of research. Before the treatment of mice, it was a satisfying adaptation for five days so that they could adapt to the environment and accelerated the absorption of the drug as well as avoided the possibility of interaction between food and serving given [10].

According to Suhardjono (2013), a factor influencing a decrease in blood glucose levels was the content of flavonoid compounds in Kersen leaves as an antioxidant so that it could secrete the insulin hormone needed for glucose metabolism [10]. Based on the analysis of researchers, the results obtained a decrease in blood glucose levels between before (pre) and after (post) in the highest decrease of 426 $\mathrm{mg} / \mathrm{dl}$ and the lowest of $79 \mathrm{mg} / \mathrm{dl}$. It indicated that after the intervention, Kersen leaves stew decreased blood glucose levels with an average difference of $141 \mathrm{mg} / \mathrm{dl}$. The presence of 3 mice that had decreased glucose levels but were still in a state of hyperglycemia based on ADA (2015) may because a genetic factor, physiological responses, and stress levels of each mouse were varied in adapting to $40 \%$ dextrose injection [11].

\subsection{Identification of decreased blood sugar levels by providing black onion extract}

The results of research on 16 mice were given black onion extract. It was obtained an average blood glucose level before administrating black onion extract by $308 \mathrm{mg} / \mathrm{dl}$. After administrating, it dropped to $155.7 \mathrm{mg} / \mathrm{dl}$.

The blood sugar levels obtained support the theory that the active compounds contained in black onions could help diabetics by guarding glucose in the blood and increasing insulin sensitivity. These active compounds are flavonoids and SAC. The SAC in black onions is two times higher, and the DADS level is 30 times higher than raw garlic (Kim, 2012). Some researchers reported that many valuable components in black onions, notably polyphenols, flavonoids, and some substances in the Maillard reaction, are already known as anti-oxidant agents. Flavonoids can restore insulin receptor sensitivity to cells, thereby reducing blood glucose levels, besides it can also repair pancreatic $\beta$ cells that have been damaged by free radicals [8]. 
Three of the Amadori and Heyns compounds in black onions increase significantly up to 40-100 times higher than garlic. Conversely, the reaction of Maillard garlic into black onion removed the unpleasant taste and smell of raw garlic. It was by inhibiting alliin to allicin because of the inactivation of alliinase heat. In addition, several studies have reported that black onion extract has antioxidant, antiallergic, anti-diabetic, anti-inflammatory, hypocholesterolemic, hypolipidemic, and anti-carcinogenic effects [12]. The research data showed a decrease in blood glucose levels between before (pre), and after (post), the highest decrease was $315 \mathrm{mg} / \mathrm{dl}$. The lowest was 68 $\mathrm{mg} / \mathrm{dl}$, although, in the group giving black onion extract, five samples had decreased blood glucose levels but still in hyperglycemia. According to ADA (2015), blood sugar levels are influenced by genetic factors, physiological responses, and stress levels in each sample that is different in adapting to the administration of dextrose $40 \%$. Thus, the administration of black onion extract is effective in reducing blood sugar levels [11].

\subsection{Analysis of differences in decreasing blood sugar by providing black onion extract and kersen leaves}

The statistical test resulted by using SPSS 16.0 with an independent sample t-test showed (2-tailed) $=0.98$ because of the value of $\alpha>$ 0.05 . Independent sample t-test was obtained p significance value of $0.005>\alpha 0.05$, so it could be concluded that there was no significant difference in the decrease in blood glucose levels before and after providing black onions and Kersen leaf stew. It could be assumed that there was no difference in both groups to decrease effectively.

In a study conducted by Rosisma (2016), garlic extract at a dose of $500 \mathrm{mg} / \mathrm{KgBB}$ or $0.5 \mathrm{ml}$ containing SAC, Allicin, and flavonoid as a source of antioxidants that can increase calcium levels in mice within seven days, but has not yet useful to reduce its glucose level [13]. Based on the researcher's analysis, a decrease in calcium levels between before (pre) and after (post) was because of the treatment given. It was by administrating black extract for 14 consecutive days with a dose of $500 \mathrm{mg} / \mathrm{Kg} \mathrm{B}$ of 16 mice, 11 mice experienced a decrease in bleeding levels to normal, and 5 mice got decreased even though it has not yet standard.

The flavonoid substance in the Kersen leaves classified into several isoflason groups. They are flavonols, catechin, and campferol flavononels, cuesertin and myrecetin. The substance of flavonols suspected to have activity in quercetin to reduce its blood glucose levels [14] The mechanism of quercetin keeps pancreatic $\beta$ cells continue to work typically. Besides, flavonoids can stimulate glucose absorption in peripheral tissues and regulate the work of enzymes involved in carbohydrate metabolism pathways [15]. Based on the above analysis, it was found that the administration of Kersen leaves can reduce blood glucose levels in mice.

\section{Conclusion}

Blood sugar levels in mice decreased significantly after the administration of black onion extract, The average decrease in blood sugar levels was $152.25 \mathrm{mg} / \mathrm{dl}$, while the standard deviation before the action was 87.12 after the treatment was 37.10 , and the reduction in blood sugar levels was 76.10. Blood sugar levels in mice decreased significantly after providing kersen leaves extract, The average decrease in blood sugar levels was $152.25 \mathrm{mg} / \mathrm{dl}$, while the standard deviation before the action was 87.12 after the treatment was 37.10 , and the reduction in blood sugar levels was 76.10 .

The statistical test results by the Independent Sample T-test in both groups showed that $p=0.98$, with a significance level of 0.05 , then $p$ $=0.98>\alpha 0.05$. Thus, H0 was accepted, and H1 was rejected, meaning that there was no significant difference in glucose levels blood in both groups of Kersen leaf stew and black onion extract. Both treatments were equally effective in reducing blood sugar levels. The administration of black onion extract and kersen leaf extract can significantly decrease blood sugar in mice, and both are equally effective.

\section{Acknowledgment}

We gratefully acknowledge the support of the University Muhammadiyah of Surabaya. The lecturer who supports to implement and complete this research of Study Program Lecturer nursing that supports the implementation of this activity until completion.

\section{Conflict of Interest}

The authors confirms that this article contains no conflict of interest.

\section{Ethical Approval}

This study was approved by the Health Research Ethics Committee (KEPK) University Airlangga, Surabaya. All participants were providede with a participant information sheet written in Bahasa Indonesia, and they signed the consnt from prior to participating in the study.

\section{References}

[1] N. J. Masfufah, Veni Hadju, "Pengetahuan, Kadar Glukosa Darah, Dan Kualitas Hidup Penderita Diabetes Mellitus Tipe 2 Rawat Jalan Di Wilayah Kerja Puskesmas Kota Makassar," Universitas Hasanuddin, 2013.

[2] Riset Kesehatan Dasar, Badan Penelitian dan Pengembangan Kesehatan. Jakarta: Kementrian Kesehatan RI, 2015.

[3] M. Taufik Perwira Wicaksono, "Diabetes mellitus tipe II gula darah tidak terkontrol dengan komplikasi neuropati diabetikum," Medula, vol. 1, no. 3, 2013.

[4] P. S. Barrat E, Zaïr Y, Ogier N, Housez B, Vergara C, Maudet C, Lescuyer JF, Bard JM, Carpentier YA, Cazaubiel M, “A combined natural supplement lowers LDL cholesterol in subjects with moderate untreated hypercholesterolemia: a randomized placebo-controlled trial," Int $J$ Food Sci Nutr, vol. 64, no. 7, pp. 882-9, 2013. https://doi.org/10.3109/09637486.2013.809405.

[5] M. M. Zahroh R., "Rebusan daun kersen menurunkan kadar gula darah pada pasien diabetes melitus tipe 2," J. Ners Community, vol. 7, no. 2, pp. $125-135,2016$

[6] S. W. Jung, E. S., Park, S. H., Choi, E. K., Ryu, B. H., Park, B. H., Kim, D. S., Kim, Y. G., \& Chae, "Reduction of blood lipid parameters by a 12wk supplementation of aged black garlic:a randomized controlled trial. Nutrition," Nutrition, vol. 30, no. 9, 2014. https://doi.org/10.1016/j.nut.2014.02.014. 
[7] O. C. Kim, J. S., Kang, O. J., \& Gweon, "Comparison of phenolic acids and flavonoids in black garlic at different thermal processing step," J. Funct. Foods, vol. 5, no. 1, pp. 80-86, 2013. https://doi.org/10.1016/j.jff.2012.08.006.

[8] B. . Rizky, "White Dragon Fruit (Hylocereus undatus) Potential As Diabetes Mellitus Treatment," Med. J. LAMPUNG Univ., vol. 4, no. 1, pp. 69$72,2015$.

[9] A. A. A. Hidayat, Metodologi Penelitian Kesehatan. Surabaya: Health Books Publishing, 2010.

[10] Gutierrez MJ et al, "Efficacy and safety of ETC-1002, a novel investigational low-density lipoprotein-cholesterol-lowering therapy for the treatment of patients with hypercholesterolemia and type 2 diabetes mellitus," Arter. Thromb Vasc Biol., vol. 34, no. 3, pp. 676-83, 2014. https://doi.org/10.1161/ATVBAHA.113.302677.

[11] American Diabetes Association, "Diabetes Mellitus and Exercise," Diabetes Care, vol. 25, no. 1, 2010.

[12] A. . Potter, P.A. \& Perry, Fundamental of nursing : concepts, process, ad practice. St.Louis: Mosby Company, 2009.

[13] W. Makalalag, I.W. Wullur, A. Adeanne dan Wiyono, "Uji Ekstrak Daun Binahong (Anredera cordifolia (Ten) Steenis) Terhadap Kadar Gula Darah Pada Tikus Putih Jantan Galur Wistar ( Rattus norvegicus) yang diinduksi Sukrosa,” J. Ilm. Farm., vol. 2, no. 1, 2013.

[14] W. wiyono Indri Wirasuasty Makalalag, Adeanne Wullur, "Uji Ekstrak Daun Binahong ( Anredera cordifolia Steen.) Terhadap kadar Gula Darah Pada Tikus Putih Jantan Galur Wistar ( Rattus norvegicus) yang Diinduksi Sukrosa,” Pharmacon, vol. 2, no. 1, 2013.

[15] Rosita, "Pengaruh Ekstrak Bawang Hitam (Black Garlick) Tehadap Penurunan Kadar Gula darah pada Mencit (mus musculus) Berdasarkan Lama Pemanasan," Akademi Analis Farmasi dan Makanan Putra Indonesia Malang, 2016. 